https://doi.org/10.25143/socr.14.2019.2.081-093

\title{
Bērna pārstāvības nodrošināšana Latvijas Republikā un izceḷojot: problēmjautājumi
}

\author{
Dr. iur. Inga Kudeikina \\ Mg. iur., Mg. paed. Sanita Vanaga \\ Rìgas Stradiṇa universitāte, Juridiskā fakultāte, Latvija \\ Inga.Kudeikina@rsu.lv \\ vanagusanita@gmail.com
}

\section{Kopsavilkums}

Rakstā aplūkoti bērna pārstāvības problēmjautājumi. Tā kā bērnam trūkst rīcībspējas, vienmēr ir nepieciešama persona, kas var bērnu pārstāvēt - vecāks, aizbildnis vai pilnvarotā persona. Sava bērna dabiskie aizbildņi, kuri bērnu pārstāv bez īpaša pilnvarojuma, ir bērna vecāki. Mūsdienās bieži ir gadỉjumi, kad zināmu laiku bērns neatrodas kopā ar vecākiem (tā iemesli var būt vecāku vai bērna ceḷojums, vecāku komandējums u. c.), tādēl vecāki faktiski nevar realizēt savus pienākumus - bērna pārstāvēšanā. Rakstā īpaša vērība veltīta kārtības, kādā bērns šḳērso Latvijas Republikas robežu, analīzei, uzmanību pievēršot bērna pārstāvības aspektiem un prettiesiskas bērna izvešanas no valsts novēršanai robežas škēērsošanas procedūru kontekstā.

Veicot tiesiskā regulējuma analīzi, tika konstatēts, ka atseviškłos gadījumos bērnam netiek nodrošināta pārstāvība. Tas ir iespējams gan gadỉjumā, kad bērna vecāki bez atbilstoša pilnvarojuma bērnu Latvijā ir nodevuši citas personas ikdienas aprūpē, gan gadījumos, kad bērns škēerso valsts robežu viens vai pilnvarotas personas pavadībā, bet pilnvarā nav pieškirirtas tiesības bērnu pārstāvēt. Šādā situācijā tiek pārkāptas bērna tiesības un tiek radīta labvēlīga augsne prettiesiskai bērna izvešanai no valsts, ḷaunprātīgi izmantojot tiesiskā regulējuma nepilnības. Pētījuma mērḳis ir identificēt problēmjautājumus un sniegt priekšlikumus tiesiskā regulējuma pilnveidošanai bērna pārstāvības jautājumos, lai novērstu iespēju bērnus prettiesiski izvest no valsts.

Raksts veidots divās dạ̣ās. Pirmajā dal̦ā aplūkoti bērna pārstāvības jautājumi, savukārt otrajā daḷā analizēta prettiesiskas bērna izvešanas problemātika bērna pārstāvības nepienācīgas nodrošināšanas dēḷ.

Atslēgvārdi: bērna pārstāvība, dokumenti bērna izcel̦ošanai, prettiesiska bērna izvešana, bērna nolaupīšana. 
Inga Kudeikina, Sanita Vanaga. Bērna pārstāvības nodrošināšana

Latvijas Republikā un izceḷojot: problēmjautājumi

\section{levads}

Apgalvojums, ka bērns ir īpašs tiesību subjekts, kuram gan nacionālos, gan starptautiskos tiesību aktos noteikta īpaša aizsardzība, vairs neprasa pierādījumus. Ne tikai tiesiskais regulējums, bet arī tiesību zinātnieki norāda, ka globalizācijas apstākḷos nodrošināt bērnu tiesības ir stratēgiski svarīgi [24;25].

Par bērnu uzskatāma persona līdz astoṇpadsmit gadu vecumam, izṇemot tās personas, kuras saskaṇā ar likumu izsludinātas par pilngadīgām vai stājušās laulībā pirms 18 gadu vecuma sasniegšanas. Tas noteikts Bērnu tiesību aizsardzības likuma 3. panta pirmajā daḷā [3].

Viens no īpašās aizsardzības mehānismiem ir aizliegums bērnu atstāt bez uzraudzības, kas transformējas plašākā prasībā - prasībā pēc bērna vecāka piekrišanas vai pilnvaras, ja bērns šḳērso Latvijas Republikas robežu. Likumā noteiktā prasība bērnu neatstāt bez uzraudzības nozīmē, ka jābūt personai, kam ir tiesības bērnu pārstāvēt. Šì prasība jāanalizē no diviem aspektiem - gadījumā, ja bērns atrodas Latvijas Republikā, un gadījumā, ja bērns šḳērso valsts robežu. Uzraudzība no stingrākas uz vājāku transformējas, bērnam pieaugot, tāpēc kārtība, kādā bērns šḳērso valsts robežu, ir atškikirīga. Lai nodrošinātu bērna tiesības, ir būtiski noskaidrot, kā tiek realizēta bērna pārstāvība, ja robežu bērns ir šḳērsojis viens vai personas, kas nav viṇa vecāks, pavadībā. Šis jautājums ir cieši saistīts ar bērna prettiesisku izvešanu no valsts, izmantojot tiesiskā regulējuma nepilnības.

Raksta mērḳis ir, izanalizējot tiesisko regulējumu, kurā noteikta kārtība, kādā bērns šḳērso Latvijas Republikas robežu, konstatēt problēmjautājumus saistībā ar bērna tiesību pārstāvības nodrošināšanu valsts robežas šḳērsošanas procedūrās, kā arī atrodoties ārzemès, lai pilnveidotu bērna tiesību aizsardzību un novērstu iespēju bērnu prettiesiski izvest.

\section{Materiāls un metodes}

Pētījumā izmantotas vispārzinātniskās pētniecības metodes un tiesību normu interpretācijas metodes - gramatiskā, vēsturiskā, teleologiskā un sistēmiskā. Tas balstìts uz tiesību aktu, tiesu prakses un zinātniskās literatūras izpētes.

\section{Bērna tiesību un interešu pārstāvība Latvijā un šḳērsojot valsts robežu}

Uzraudzības faktiskās izpausmes būs atšḳirīgas, piemēram, divus gadus vecam bērnam un 16 gadus vecam bērnam. Saskaṇā ar Bērnu tiesību aizsardzības likuma 24. panta sesto daḷu [3] vecākiem vai personai, kuras aprūpē bērns nodots, ir pienākums neatstāt bērnu līdz septinu gadu vecumam bez pieaugušo vai personu, ne jaunāku par 13 gadiem, klātbūtnes. Tātad likumdevējs expresis verbis ir noteicis, ka bērns līdz 
septiņu gadu vecumam fiziski nedrīkst būt viens. Gramatiski tulkojot tiesību normu, jāsecina, ka pēc septinnu gadu vecuma bērns var palikt bez uzraudzības. Tomēr, analizējot bērna tiesības kopsakarā ar vecāku pienākumiem, jāsecina, ka minētais apgalvojums nav viennozīmīgs. Proti, jebkurā gadījumā par bērnu, tā drošību, bērna tiesību ievērošanu visplašākajā izpratnē atbildīgi ir vecāki. Tas izriet gan no Civillikuma 177. panta [4], kurā noteikts, ka līdz pilngadības sasniegšanai bērns ir vecāku aizgādībā, gan no Bērnu tiesību aizsardzības likuma 24. panta pirmās dalıas [3], kurā, precizējot vecāku aizgādības saturu, noteikts, ka atbilstoši Civillikuma noteikumiem vecāku pienākums ir rūpēties par bērnu un viņa mantu un pārstāvēt bērnu viṇa personiskajās un mantiskajās attiecībās. Turklāt, kā minēts Civillikuma 1408. panta pirmajā dạ̦ā [5], jāṇem vērā, ka bērnam trūkst rīcībspējas un ka šì iemesla dēl viņš nevar pilnā apmērā realizēt savas tiesības. Jāsecina, ka bērna iespējas pārstāvēt sevi ir ierobežotas, tāpēc vecākiem bez sevišķa pilnvarojuma uz likuma pamata kā dabiskajiem aizbildṇiem ir tiesības pārstāvēt bērnu.

Dažādu iemeslu dēḷ bieži ir situācijas, kad bērns neatrodas kopā ar vecāku/vecākiem. Piemēram, bērns ir devies ceḷojumā, atrodas laukos pie vecmāmiņas, piedalās sacensībās vai uzstājas koncertā. Jāuzsver, ka bērns var atrasties šķirti no vecākiem gan Latvijā, gan ārpus tās.

Kas tādos gadījumos pārstāv bērna intereses un aizsargā vina tiesības?

Ja bērns ir šķirts no vecākiem, bet atrodas Latvijā, tad tiesiskais regulējums neparedz ìpašas prasības pilnvarotajai personai, kuras aprūpē bērns nodots un pie kuras bērns atrodas. Bērna vecāku izsniegta rakstveida pilnvara nav obligāta. Vienīgā prasība ir iepriekšminētais universālais nosacījums, ka bērns līdz septinnu gadu vecumam fiziski nevar atrasties viens. Tomēr jāuzsver, ka šis regulējums attiecas tikai uz ikvienas personas, kurai bērns uzticēts, pienākumu nodrošināt bērna fizisku uzraudzību. Personai, kurai nodots bērns, neatkarīgi no tā, vai šì persona ir vai nav bērna radinieks, nav bērna pārstāvības tiesību. Tātad gadījumos, kad bērns atrodas, piemēram, pie vecmāmiñas, bērna vecāki saglabā savas tiesības un pienākumus pilnā apmērā. Tie nepāriet uz personu, kurai bērns tobrīd tiek uzticēts. Šādos gadījumos ir jāatšḳir faktiskā un tiesiskā atbildība par bērnu. Ikdienas aizgādība, kurā ietilpst rūpes par bērna fizisko un emocionālo drošību, èdienu, pajumti u. tml., ir personai, kurai bērns nodots, bet tiesiski atbildīgi par bērnu ir viņa vecāki. Arī kontrole un atbildība par to personu, kurai vecāki bērnu ir uzticējuši, ir pašu vecāku atbildības lauks. Vecākiem ir rūpīgi jāizvērtē personas, kurai bērns tiek uzticēts, spējas rūpēties par bērnu.

Atsevišķa uzmanība jāvelta gadījumiem, kad nepieciešama bērna pārstāvība attiecībās ar trešajām personām, piemēram, ārstniecības personām. Saskaṇā ar Pacientu tiesību likuma 13. panta pirmo daḷu nepilngadīga pacienta (lìdz 14 gadu vecumam) ārstniecība piel̦aujama, ja viņa likumiskais pārstāvis par to ir informēts un devis savu piekrišanu [14]. Arī zinātniskajā literatūrā ir norādīts uz pilnvarojuma sniegt ārstēšanas aț̣auju būtisko nozìmi, jo tajos gadījumos, kad pacients veselības stāvokḷa vai vecuma dēl nespēj pieņemt lēmumu par ārstniecību, šìs pacienta ekskluzivās tiesības izlemt par savu veselību un dzīiibu tiek nodotas trešajām personām [23, 452]. 
Savukārt no Pacientu tiesību likuma 13. panta trešajā dạ̦ā minētā izriet, ka likumiskā pārstāvja piekrišana ir nepieciešama arī gadījumos, kad nepilngadīgs pacients, kas sasniedzis 14 gadu vecumu, atsakās dot savu piekrišanu ārstniecībai, bet ārstniecības persona uzskata, ka ārstniecība ir pacienta interesēs. Nododot bērnu citas personas aprūpē, bērns var nesaṇemt nepieciešamo ārstniecību.

Secināms, ka bērna nodošana citas personas aprūpē, neizsniedzot šai personai pilnvaru, var būtiski ietekmēt bērna tiesības. Savukārt tas var tikt traktēts kā bērna tiesību pārkāpums. Šāda nostāja ir atspogulota arī tiesu praksē. Autores pievienojas Administratīvās rajona tiesas apsvērumiem lietā Nr. A420436613 par to, ka bērna vislabākajās interesēs ir, lai viņš nepaliktu bez personas, kas īsteno tā aizgādību un pilnvērtīgi var viṇu pārstāvēt jebkurā dzīves situācijā. Tiesa ir atzinusi, ka nav būtiski, ka bērnam nav ticis nodarīts kaitējums. Jau tas vien, ka nav personas, kurai atbilstoši dotas tiesības bērnu pārstāvēt, rada bērnam bīstamus apstākḷus [25].

Kaut gan tiesību aktos nav konkrēti noteikta prasība, nododot citas personas aprūpē bērnu, izsniegt šai personai pilnvaru bērna interešu pārstāvībai, tas, ka nepieciešama pilnvara, secināms no Bērnu tiesību aizsardzības likuma normām, tulkojot tās sistēmiski un kopsakarā ar Civillikumā noteiktajiem vecāku pienākumiem. Šajā sakarā, ievērojot praksē gūtos novērojumus, ka vecāki, nododot bērnus citu personu aprūpē (īpaši aprūpē uz neilgu laika posmu, piemēram, līdz mēnesim), tomēr salīdzinoši reti izsniedz šīm personām pilnvaras, raksta autores rosina diskusiju par iespēju ar konkrētu tiesību normu paredzēt, ka šāda pilnvara ir obligāta.

Šãdai prasībai jābūt absolūtai, jo nav pamatojuma noteikt minimālo termiṇu, uz kuru bērnu var nodot citas personas aprūpē bez pilnvaras. Galvenokārt tas saistìts ar ārstniecības pakalpojumu saṇemšanas nodrošināšanu. Nepieciešamība pēc tiem var rasties arī laikā, kad bērns nodots citas personas aprūpē.

Citāda kārtība paredzēta, ja bērns šḳērso Latvijas Republikas robežu. Tā noteikta Latvijas Republikas Ministru kabineta 2010. gada 3. augusta noteikumos Nr. 721 "Kārtība, kādā bērni šḳērso valsts robežu” [7]. Protams, visos gadījumos bērnam ir nepieciešams personu apliecinošs dokuments. Jāuzsver, ka atkarībā no bērna vecuma un tā, vai tiek šķērsota Eiropas Savienības ārējā robeža, ir paredzēti dažādi procesuālie dokumenti bērna izcel̦ošanai no valsts. Ja bērns dodas uz valsti, kas ir Eiropas Savienības dalībvalsts, Šengenas līguma dalībvalsts vai uz Lielbritānijas un Ziemeḷīiijas Apvienotā Karalisti, papildu dokumenti no bērna vecākiem (aizbildṇiem) nav nepieciešami.

Bērna tiesības izcelıtot no valsts un doties uz valsti, kas nav Eiropas Savienïbas dalībvalsts, Šengenas līguma dalībvalsts vai Lielbritānijas un Ziemeḷīijas Apvienotā Karaliste, apliecina vismaz viena vecāka izdota un notariāli apliecināta pilnvara vai notariāli apliecināta piekrišana, ka bērns, kurš sasniedzis septiṇu gadu vecumu, izceḷo viens. Septiņu gadu vecuma robeža tiek noteikta, pamatojoties uz iepriekš minētā Bērnu tiesību aizsardzības likuma 24. panta sestajā daḷā rakstīto, proti, bērnam sasniedzot septinu gadu vecumu, atkrīt pienākums nodrošināt tā atrašanos citas personas, ne jaunākas par 13 gadiem, uzraudzībā. 
Izcel̦ojot pilnvarotās personas pavadỉbā, var tikt nodrošināta bērna interešu un tiesību pārstāvība. Proti, pamatojoties uz praksē gūtajiem novērojumiem, tādas tiesības parasti tiek paredzētas pilnvarotajām personām. Tomēr jāuzsver, ka pilnvarot pārstāvēt bērnu ir vecāku tiesības, nevis pienākumus. Raksta autores nevar apgalvot, ka it visās pilnvarās, kas izsniegtas personām, kas pavada bērnu ceḷojumos, pilnvarotajām personām ir piešḳirtas tiesības bērna tiesības pārstāvēt cel̦ojuma laikā.

Tādējādi var secināt, ka spēkā esošais tiesiskais regulējums piel̦auj situācijas, kurās bērnam, izcel̦ojot ārpus Latvijas Republikas robežas, netiek nodrošināta viṇa interešu un tiesību pārstāvība. Turklāt tas, ka ir pilnvarotā persona, nenodrošina, ka tiks pārstāvētas bērna tiesības.

Esošais tiesiskais regulējums par kārtību, kādā bērni škēerso Latvijas Republikas robežu, ir vērtējams kritiski. Bērna atrašanās bez personas, kurai ir tiesības pārstāvēt bērnu, ir uzskatāma par bērna tiesību būtisku pārkāpumu. Kā jau iepriekš tika minēts, ir precedenti, kad bērna nodošanu citas personas aprūpē bez pienācīga personas pilnvarojuma tiesa atzīst par pamatu vecākam atṇemt aizgādības tiesības aprūpes pienākumu nepildīšanas dēḷ. Turklāt, ievērojot, ka pilnvarot citu personu pārstāvēt bērnu bez bārintitiesas piekrišanas iespējams uz laiku, kas nepārsniedz trīs mēnešus (tas noteikts Bērnu tiesību aizsardzības likuma $45^{1}$. panta pirmajā dạ̦ā [3]), ir neizprotama likumdevēja nostāja aț̣aut bērnam vienam vai pilnvarotās personas, kura var būt bez tiesībām pārstāvēt bērnu, šḳērsot Latvijas Republikas valsts robežu. Tātad, esot Latvijā, bērna tiesības un to ievērošana tiek uzraudzìta un kontrolēta, bet, bērnam šḳērsojot robežu, šìs prasības netiek ievērotas.

Protams, jāievēro likuma spēkā esamība telpā, t. i., Latvijas Republikas tiesību akti nebūs spēkā ārpus Latvijas Republikas. Taču bērns arī pēc robežas šķērsošanas joprojām ir Latvijas Republikas valsts piederīgais, un valsts uzdevums ir maksimāli nodrošināt tā tiesību ievērošanu. Tiesiskajā regulējumā būtu jāparedz, ka vecākiem ir obligāti jānodrošina pilnvarotā persona, kura būtu tiesīga bērnu pārstāvēt ārpus Latvijas Republikas robežām. Proti, gadījumos, kad bērns izceḷo pilnvarotās personas pavadībā - pilnvarā obligāti jābūt paredzētām pilnvarotās personas tiesībām pārstāvēt bērna tiesības, savukārt, ja bērns ir vecāks par septiniiem gadiem un izceḷo viens uz vecāka izsniegtas piekrišanas pamata, arī tad ir jābūt šì bērna pilnvarotai personai, kura ir tiesīga bērnu pārstāvēt valstī, uz kuru bērns izceḷo. Tas var būt skolotājs, treneris, ğimenes draugs u. tml., jo piel̦aujams, ka bērns tomēr būs kādas pieaugušas personas faktiskā pavadībā.

Šāds risinājums palīdzētu novērst bērna prettiesisku izvešanu no valsts, jo katrā konkrētā gadījumā notiktu aprūpes tiesību delegéěšana, bērns sekotu personai, kas ir tiesīga vinu pārstāvēt, un tiktu novērstas iespējamas manipulācijas ar bērna tiesisko stāvokli laikā, kad neviens no vecākiem vinu nepārstāv.

Analizējot tiesisko regulējumu prettiesiskas bērna izvešanas gadījumu kontekstā, izgaismojas vēl viena problēma. Minētie Ministru kabineta noteikumi "Kārtība, kādā bērni šḳērso valsts robežu" nosaka, ka gan piekrišanu, gan pilnvaru robežas šḳērsošanai ir tiesīgs dot viens no vecākiem, ja viņš ir Latvijas pilsonis, Lat vijas nepilsonis, Eiropas Savienības 
dalïbvalsts, Eiropas Ekonomikas zonas valsts, Šveices Konfederācijas vai Lielbritānijas un Ziemel̦īiijas Apvienotās Karalistes pilsonis vai bezvalstnieks, kam piešḳirts bezvalstnieka statuss Latvijas Republikā, Eiropas Savienības dalībvalstī, Eiropas Ekonomikas zonas valstī, Šveices Konfederācijā vai Lielbritānijas un Ziemeḷīijas Apvienotajā Karalistē.

Civillikuma 178. pantā noteikts, ka kopā dzīvojoši vecāki aizgādību īsteno kopīgi un arī tad, ja vecāki ir šksirti, kopīga aizgādība turpinās, izn,emot gadỉjumus, kad nodibināta viena vecāka atseviškła aizgādība. Vecākiem kopīgi jāpieņem visi lēmumi, kas var būtiski ietekmēt bērnu. Bērna izcel̦ošana ārpus Latvijas Republikas uzskatāma par notikumu, kam ir būtiska nozīme. Šāds apgalvojums saistīts ar iespējamību, ka bērns var neatgriezties Latvijā un faktiski izveidoties strīdus situācija, ka bērns, kurš tiesiski atstājis valsti (t. i., ar viena vecāka piekrišanu), prettiesiski netiek atvests atpakalı.

Šādas iespējamības izslēgšanai lietderīgi ir noteikt, ka jebkuras piekrišanas un pilnvaras, uz kuru pamata bērns ir tiesīgs šḳērsot Latvijas Republikas robežu, ir tiesīgi pien,emt tikai abi vecāki kopā, t. i., piekrišanu vai pilnvaru izsniedz abi vecāki. Jānorāda, ka viena vecāka atsevišḳ aizgādība var tikt noteikta ar tiesas spriedumu vai vecākiem par to vienojoties, kā tas ir noteikts Civillikuma 178. panta ceturtajā dạ̄ā. Tomēr fakts, ka ir nodibināta viena vecāka atsevišķa aizgādība, publiskos registros netiek fiksēts. Tā ir informācija, kas ir zināma tikai pašiem vecākiem un kuru nav iespējams pārbaudīt nedz zvērinātiem notāriem, nedz robežsargiem. Tāpēc ir iespējams, ka vecāks l̦aunprātīgi izmanto situāciju, ka nav šāda atseviškłas aizgādības tiesību reg̣istra, un bērns tiek izvests, neinformējot par to otru vecāku vai pret otra vecāka gribu. Atsevišḳas aizgādības tiesību regiistrs lautu pilnveidot tiesisko regulējumu. Reǵistra vešana varētu tikt uzticēta bāriṇtiesai kā institūcijai, kas izveidota bērna interešu aizsardzībai, kā tas paredzēts Bāriṇtiesu likuma 4. panta otrajā dạ̦ā [2], vai zvērinātiem notāriem, kuriem ir pieredze un tehniskās iespējas vest un uzturēt dažādus reǵistrus (piemēram, mantojuma lietu reǵistru, atsaukto pilnvarojumu, nākotnes pilnvarojumu) atbilstoši Notariāta likumam [13].

\section{Fakta konstatēšana par prettiesisku bērna izvešanu no valsts}

Kā iepriekš minēts, saskaṇā ar nacionālajiem tiesību aktiem bērnu intereses pārstāv viṇu likumiskie pārstāvji - dabiskie aizbildṇi, kas ir vecāki vai likumiskie aizbildṇi, kas ir iecelti ar bāriṇtiesas lēmumu. Lai gan prettiesiskas bērna izvešanas no valsts gadījumā par pamatu nav uzskatāmi aizgādības tiesību jautājumi, tomēr jānnem vērā, ka saskaṇā ar Civillikuma 178. panta ceturto dalı vecāki pār bērnu îsteno kopīgu aizgādību līdz brīdim, kad ir savstarpēji vienojušies par atsevišşu aizgādību, vai ar tiesas nolēmumu tiek nodibināta viena vecāka atsevišķa aizgādība [4]. Galvenokārt tieši no minētās tiesību normas izriet bērna likumiskā pārstāvja turpmākās rīcības formula, jo šajā likumā noteikts, vai bērna izvešana no valsts ir tiesiska vai prettiesiska. Ikvienam bērna likumiskajam pārstāvim primāri ir jān̨em vērā, ka bērna interesēs ir ievērot pastāvošo tiesisko regulējumu, kurā noteikts, ka bērna likumiskajiem pārstāvjiem, kas īsteno kopīgu bērna aizgādību, 
neatkarīgi no tā, vai gimenē vecāki dzīvo kopā vai šḳirti, līdz laikam, kamēr pār bērnu nav nodibināta atsevišḳa aizgādība, ir absolūti vienādas tiesības lemt jautājumus, kas skar bērna tiesības un intereses.

Par prettiesisku rīcību jeb prettiesisku darbību tiek uzskatīta jebkura darbība, kas nesakrīt ar tiesību normu prasībām, neatbilst tiesiskiem priekšrakstiem, ir pretrunā ar tiesību normām, kuru neprasa un nepiel̦auj tiesību norma un ir pretrunā likumam. Prettiesiska darbība var būt arī civila, un tas var būt par pamatu aizsargājošām tiesiskām attiecībām, kā arī vainīgo saukšanai pie atbildības [21;261]. Saskaņā ar prettiesiskas rīcības definīciju ir jāṇem vērā, ka bērna prettiesisku izvešanu no valsts var īstenot ne tikai bērna likumiskie pārstāvji, bet arī trešās personas un institūcijas.

2001. gada 23. oktobrī Latvija, pieṇemot likumu "Par Hāgas konvenciju par starptautiskās bērnu nolaupīšanas civiltiesiskajiem aspektiem" [15], ir ratificējusi 1980. gada Hāgas konvenciju par starptautiskās bērnu nolaupišanas civiltiesiskajiem aspektiem, kura nosaka prettiesiskas bērnu aizvešanas un aizturēšanas apstākḷus, bet uz izstrādātās rīcības pamata nodrošina ātru bērnu atgriešanos viṇu pastāvīgajā dzīvesvietas valstī, nodrošinot situācijas atjaunošanu, pirms bērns tika prettiesiski izvests no valsts [9]. Vienlaikus Latvijai ir saistoša 2003. gada 27. novembra Eiropas Savienības Padomes regula Nr. 2201/2003, ar kuru tiek noteikta jurisdikcija, spriedumu atzīšana un vecāku atbildība, tostarp lietās par bērnu prettiesisku izvešanu no valsts [16]. Savukārt tiesiskajā regulējumā, kas ietverts 1996. gada Hāgas konvencijā par jurisdikciju, piemērojamiem tiesību aktiem, atzī̌̌anu, izpildi un sadarbību attiecībā uz vecāku atbildību un bērnu aizsardzības pasākumiem, noteiktas dalībvalstu kompetentās jeb centrālās iestādes, kuras pien̦em pagaidu un ārkārtējus lēmumus, lai nodrošinātu bērnu tiesību aizsardzību starptautiskā līmenī ar aizgādību un saskarsmes tiesībām saistītās pārrobežu lietās [10]. Saskaņā ar 1980. gada Hāgas konvencijas 3. pantu prettiesiska bērna izvešana no valsts uzskatāma gadījumā, kad personas, institūcijas vai kādas citas iestādes, kuras bērnu prettiesiski ir izvedušas no valsts, nav ievērojušas tās valsts likumdošanu, kurā bērns pastāvīgi dzīvoja tieši pirms aizvešanas [9]. No minētā var secināt, ka prettiesiskas bērna izvešanas no valsts fakts konstatējams, vadoties no tās valsts likumiem, no kuras bērns ir izvests, vienlaikus ņemot vērā, kura valsts ir atzīstama par bērna pastāvīgo dzīvesvietu. Savukārt saskaṇā ar dzīvesvietas definīciju, par pastāvīgu dzīvesvietu uzskatāma vieta, kur persona pēc savas gribas apmetusies ar nodomu tur pastāvīgi dzīvot [18; 48].

Latvijā bērnu tiesības ir noteiktas Latvijas Republikas Satversmes [11] VIII nodaḷā kā ikviena cilvēka pamattiesības, savukārt Satversmes 98. pantā paredzēts, ka ikvienai personai ir tiesības brīvi izbraukt no Latvijas un ikviens, kam ir Latvijas pase, ārpus Latvijas atrodas valsts aizsardzībā un saglabā tiesības brīvi atgriezties Latvijā [11]. Tātad arī Satversmē garantētas bērna tiesības atgriezties Latvijā un noteikts, ka valstij ir tiesības bērnu aizsargāt prettiesiskas pārvietošanas gadījumā. Vienlaikus Bērnu tiesību konvencijas 35. pantā paredzēts, ka, nodrošinot ikviena bērna pamattiesības, ikvienai dalïbvalstij jāveic visi iespējamie pasākumi, lai novērstu bērnu nolaupišanu [1]. 
Inga Kudeikina, Sanita Vanaga. Bērna pārstāvības nodrošināšana

Latvijas Republikā un izceḷojot: problēmjautājumi

Jāatzīmē, ka, ievērojot iepriekšminēto, jāizškịir ceḷošanas un dzīvesvietas maiṇas ārpus valsts robežām jēdzienu būtība. Abos gadījumos tiek šḳērsota valsts robeža, tomēr ar dažādu mērḳi. Pirmajā gadỉjumā valsts robeža tiek šḳērsota, lai ārvalstīs uzturētos ìstermin̄ā, noteiktu laika posmu, bet otrajā gadījumā - lai ilglaicīgi paliktu citā valstī. Lai izvairītos no prettiesiskas bērna izvešanas no valsts, būtiski ir ievērot nacionālajos tiesību aktos noteikto kārtību, kā bērnam tiesiski šķērsot valsts robežu, un nepieciešamības gadijumā faktu par bērna tiesisku izcel̦ošanu no valsts fiksēt rakstveidā.

Latvijas Republikas valsts robežas likuma 10. panta pirmajā, ceturtajā un piektajā dal̦ā paredzēts, ka valsts robežu var šḳērsot pa sauszemi, iekšējiem ūden̦iem, jūru vai gaisa telpu ar derīgiem ceḷošanas dokumentiem un citiem dokumentiem, kuru nepieciešamība ir noteikta normatīvajos aktos, savukārt to, kā bērnam tiesiski jāšķērso valsts robeža, noteicis Ministru kabinets [12]. Kā jau iepriekš tika norādīts, Latvijas tiesiskajā regulējumā paredzēts, ka gadỉjumā, ja bērns, kurš ir Latvijas valsts piederīgais, izceḷo no valsts, tās personas pavadībā, kura ir tiesiski pilnvarota pavadìt bērnu, škēersojot valsts robežu, šai personai ir nepieciešams uzrādìt vismaz viena vecāka vai aizbildṇa notariāli apliecinātu pilnvaru. Ja vecāks, kurš ir tiesīgs izdot pilnvaru, nav sasniedzams vai atsakās izdot pilnvaru, bērns šḳērsot valsts robežu var citas personas pavadībā, uzrādot bāriṇtiesas lēmumu par atḷaujas došanu šḳērsot valsts robežu attiecīgās personas pavadībā. Savukārt ja bērns izceḷo no valsts aizbildṇa pavadībā, nepieciešams uzrādīt bāriṇtiesas lēmumu par aizbildnības nodibināšanu vai minētā lēmuma apliecinātu kopiju. Minētajos gadījumos notariāli apliecināta pilnvara nav nepieciešama, ja bērns valsts robežu šḳērso bāriṇtiesas pārstāvja pavadībā, lai izpildītu nolēmumu par bērna atgriešanos valstī. Ievērojot tiesiskajā regulējumā noteikto, gadījumā, ja bērns šḳērso valsts robežu vecāka pavadībā, papildus bērna personu apliecinošam dokumentam jāuzrāda vecāka personu apliecinošs dokuments, ar kuru tiek pierādìta radniecība ar bērnu, un bērna dzimšanas apliecības oriǵināls vai tā kopija, ja pavadošā vecāka personu apliecinošā dokumentā nav uzrādīta radniecība ar bērnu.

Problēmjautājums ir saistīts ar to, ka vecāks ir tiesīgs izvest bērnu bez otra vecāka piekrišanas kopīgas aizgādības gadījumos, ievērojot, ka valstī nepastāv vienots pilnvaru un/vai atsevišḳas aizgādības lēmumu reg̣istrs. Bārenis vai bez vecāku gādības palicis bērns valsts robežu tiesiski var šḳērsot patstāvīgi vai pilnvarotās personas pavadībā, uzrādot bāriṇtiesas lēmumu par aț̣aujas došanu, šḳērsot valsts robežu patstāvīgi vai pilnvarotās personas pavadībā. Savukārt Pilsonības un migrācijas lietu pārvalde pēc izglìtības iestāžu pieprasijuma izsniedz un apstiprina cel̦otāju sarakstu izglìtības iestādes rīkotajām ekskursijām Eiropas Savienībā, kam atbilstoši tiek pievienoti pārējie personu apliecinošie dokumenti. Savukārt tikai trīs gadījumos ir noteikts, ka pilnvara bērna valsts robežas šksērsošanai nav nepieciešama, proti, ja otrs vecāks nav sasniedzams vai atsakās dot piekrišanu bērna izcelıošanai no valsts; neviens no vecākiem nav Latvijas pilsonis vai nepilsonis [..]; un saskaņā ar Latvijas tiesas nolēmumu vai nolēmumu un apliecību, ko ārvalsts tiesa vai kompetentā iestāde izsniegusi par bērna atgriešanos valstī, kurā ir viṇa dzīvesvieta [7]. Tādēl var secināt, ka bērns valsts robežu šḳērso prettiesiski šādos 
gadïjumos: bērna pilnvarotajam pārstāvim nav notariāli apliecinātas pilnvaras vai bāriṇtiesas lēmuma, ar kuru tiek atḷauts šḳērsot valsts robežu attiecīgās personas pavadībā, ja nav otra vecāka pilnvaras jeb piekrišanas bērna izvešanai no valsts vai apliecinošu dokumentu, ka bērna likumiskais pārstāvis īsteno atsevišḳu aizgādību, vai bērns tiek atgriezts atpakal pastāvīgās dzīvesvietas valstī. Faktiski jāsecina, ka tiesību aktos nav atrunāta norma, kura paredz, ka minētie dokumenti nepieciešami tikai dzīvesvietas main̦as, cel̦ošanas vai abos gadïjumos, kad tiek šķērsota valsts robeža. Vienlaikus tiesību aktos nav noteikta kārtība, ka minētās pilnvaras nepieciešamas tikai gadījumos, kad bērna vecāki dzīvo šḳirti.

Lai tiktu konstatēts un apstiprināts fakts, ka bērns ir prettiesiski izvests no valsts, cietušajai personai, kas lielākajā dal̦ā gadījumu ir bērna vecāks, kura uzskata, ka ir pārkāptas viņas tiesības uz aizgādību un saskarsmes īstenošanu ar bērnu, ir jāvēršas Tieslietu ministrijā vai tās valsts centrālajā iestādē vai tiesā, uz kuru bērns ir prettiesiski aizvests vai kurā aizturēts [20]. Ar 2007. gada 15. maija Ministru kabineta noteikumiem Nr. 322 "Kārtība, kādā Latvijas centrālā iestāde atbilstoši 1980. gada 25. oktobra Hāgas konvencijai par starptautiskās bērnu nolaupišanas civiltiesiskajiem aspektiem veic tajā minētās darbības un sadarbojas ar citām valsts un pašvaldību iestādēm" [8] noteikta Latvijas centrālās iestādes kompetence un darbība, nodrošinot no valsts prettiesiski izvesta bērna tiesības un intereses. Jāṇem vērā, ka fakta konstatēšana par bērna prettiesisku izvešanu no valsts un atgriešanu atpakal bērna pastāvīgās dzīvesvietas valstī Latvijā tiek izskatìta Civilprocesa likuma $644^{13}$. un $644^{14}$. panta kārtībā [6], kā arī, ievērojot iepriekš pieminēto nacionālo un starptautisko tiesisko regulējumu.

Pieteicējam, kurš konstatējis, ka bērns ir prettiesiski izvests no valsts, pieteikuma pamatdokumentiem, kas apliecina viṇa radniecību ar bērnu jeb likumisko pārstāvību, pamatojoties uz bāriṇtiesas lēmumu vai tiesas spriedumu, pievieno pierādījumus, kas, pamatojoties uz nacionālajiem tiesību aktiem, apliecina bērna prettiesisku izvešanu no valsts, piemēram, tiesas lēmums vai spriedums par aizliegumu bērnu izvest no valsts, vecāku rakstisks atteikums bērna izvešanai no valsts, izziņa no policijas. Piemēram, balstoties uz Personu apliecinošu dokumentu likuma 10. pantu, vecāks Pilsonības un migrācijas lietu pārvaldē var iesniegt iesniegumu, kurā lūgt neizsniegt bērna otram likumiskajam pārstāvim bērna personu apliecinošus dokumentus [17]. Šādā gadījumā tiek izteikta bērna likumiskā pārstāvja griba un bērna personu apliecinošie dokumenti netiek izsniegti vienu mēnesi vai tik ilgi, cik to noteikusi tiesa nolēmumā par bērna aizliegumu izvest no valsts vai tiesvedỉbas izbeigšanai.

Atbilstoši Civilprocesa likuma 8. panta pirmajai dal̦ai tiesa noskaidro lietas apstākḷus, pārbaudot likumā noteiktajā kārtībā iegūtos pierādījumus. Savukārt saskaṇā ar minētā tiesību akta 93. panta pirmo daḷu katrai pusei ir jāpierāda tie fakti, uz kuriem tā pamato savus prasījumus un iebildumus [6]. Civilprocesā būtiska nozīme tiek pieškirta pierādījumiem un pierādī̌sanas procesam, ko nodrošina procesā ieinteresētās personas, tādēḷ ne vienmēr ir iespēja nonākt pie objektīvas patiesības. Patiesības atspoguḷojums ir atkarīgs no tā, cik katra no iesaistītajām pusēm ir ìstenojusi civilprocesam raksturīgo 
sacīkstes principu [22; 34]. Profesors Vladimirs Bukovskis norādījis, ka cīnuu uzvar tas, kurš tiesas priekšā pierāda savu taisnību, pamatojoties uz tiesai iesniegtajiem pierādījumiem [19; 235]. No minētā var secināt, ka bērna izvešana no valsts pati par sevi nevar būt pamats fakta par bērna prettiesisku izvešanu no valsts konstatēšanai. Lai šo faktu pierādītu, būtiski ir gūt pierādījumus, ar kuriem apstiprināms minētais apgalvojums. Saskaṇā ar iepriekšminētajām tiesību normām tie ir: rakstiska pilnvara, rakstiski noformēts aizliegums vai tiesas nolēmums par aizliegumu bērnu izvest no valsts.

Lai gan ANO konvencijas par bērnu tiesībām 12. pantā [1] un Bērnu tiesību aizsardzības likuma 13. panta pirmajā dạ̦ā [3] paredzētas bērna tiesības formulēt viedokli atbilstoši bērna vecumam un viņa brieduma pakāpei un tiesības tikt uzklausītam jebkurā ar vinu saistītā lietā, gadỉjumā, kad konstatēta prettiesiska bērna izvešana no valsts, tiesu praksē bērna viedoklim netiek pieškirirta pierādỉjumu nozīme. Latvijas Republikas Augstākā tiesa 2015. gada 27. novembra lietā Nr. SKA-1142/2015 atsaukusies uz Eiropas Cilvēktiesību tiesas 2015. gada 21. jūlija spriedumu lietā "G.S. pret Gruziju” (iesnieguma Nr. 2361/13), kurā pausta atziṇa, ka bērna viedoklis var radìt nepamatotas priekšrocības vecākam, kurš bērnu prettiesiski ir aizvedis. Ir jāṇem vērā apstāklis, cik ilgi bērns atrodas prombūtnē kopā ar vecāku, kurš bērnu ir prettiesiski izvedis no valsts. Jo ilgāks ir laika posms, jo neobjektīvāks var kḷūt bērna viedoklis [28].

Analizējot tiesu praksi (Latvijas Republikas augstākās tiesas Administratìvo lietu departamenta 27.11.2015. spriedums lietā Nr. SKA-1142/2015 [28], Eiropas Cilvēktiesību tiesas 26.11.2013. spriedums lietā X pret Latviju, iesnieguma Nr. 27853/09 [26], Latvijas Republikas Augstākās tiesas Civillietu departamenta 2017. gada lēmums lietā Nr. SKC[D]/2017 [27]) pārrobežu lietās, kas saistītas ar prettiesisku bērnu izvešanu no valsts, vērojama lietas dalībnieku tendence iesniegt pierādỉjumus, kas saistīti ar pušu personisko interešu nodrošināšanu, kā pamatu akcentējot bērnu vislabākās intereses. Latvijas Republikas Augstākās tiesas Civillietu departaments atbilstoši Eiropas Cilvēktiesību tiesas iedibinātai tiesu praksei starptautiskās bērnu nolaupīšanas jomā paudis atziṇu, ka galvenais ir panākt taisnīgu līdzsvaru starp konkurējošām bērnu, abu vecāku un sabiedrības kārtības interesēm, ievērojot rīcības brīvības tiesības, kas minētajos jautājumos ir piešķirtas līgumslēdzēju valstīm. Vienlaikus jānemem vērā, ka pārrobežu jautājumi nevar tikt izskatīti mehāniski [27]. Lai gan tiesu praksē nav aktuāla fakta konstatēšana par bērnu prettiesisku izvešanu no valsts kā atsevišşss process, visos minētajos tiesu prakses gadījumos tiesa primāri ir vērtējusi bērna izvešanas no valsts tiesiskumu, proti, vai ir vecāku savstarpēja vienošanās par bērna izvešanu aiz valsts robežas, vai ir saṇemta otra vecāka piekrišana bērna izvešanai no valsts un vai šāda piekrišana bērna pastāvīgās dzīvesvietas valsts tiesiskajā regulējumā ir paredzēta. Minētie apstākḷi ir galvenie pierādījumi fakta par bērna prettiesisku izvešanu no valsts konstatēšanai. 
Inga Kudeikina, Sanita Vanaga. Bērna pārstāvības nodrošināšana

Latvijas Republikā un izceḷojot: problēmjautājumi

\section{Secinājumi}

Tiesiskais regulējums, kurā noteikta bērna pārstāvība, atzīstams par nepilnīgu, jo tiek piel̦autas situācijas, ka nav personas, kurai ir tiesības pārstāvēt bērnu konkrētā laikā un vietā. Šādas situācijas iespējamas gan gadījumā, ja bērns ir Latvijā, gan gadījumā, ja tas šḳērso Latvijas Republikas robežu - gan robežas šḳērsošanas brīdī, gan esot jau ārzemēs. Tiesību aktos nav noteikta prasība vecākam, kurš nodod bērnu uz laiku citas personas ikdienas aizgādībā Latvijā vai ārpus tās, vai bērnam, kurš sasniedzis septiṇu gadu vecumu, šḳērsojot valsts robežu vienam, pilnvarot kādu personu pārstāvēt bērna tiesības un intereses. Tādējādi tiek aizskartas bērna tiesības, jo konkrētā laikā un vietā nav personas, kas tiesīga bērnu pārstāvēt. Vecāku pārstāvības tiesības šajā brīdī kḷūst par fikciju, jo, faktiski neatrodoties kopā ar bērnu, vecāku pārstāvības tiesībām nav izšḳirošas nozīmes.

Tas, ka nepastāv atsevišḳs aizgādības tiesību registrs, rada iespēju negodprātīgam vecākam prettiesiski izmantot savas vecāka tiesības un pien,emt vienpersonisku lēmumu par bērna izvešanu no Latvijas Republikas, neprasot otra vecāka piekrišanu gadījumos, kad aizgādību īsteno abi vecāki kopīgi. Proti, ja abi vecāki ir Latvijas pilsoṇi, Latvijas nepilsoṇi, Eiropas Savienības dalībvalsts, Eiropas Ekonomikas zonas valsts, Šveices Konfederācijas vai Lielbritānijas un Ziemel̦īiijas Apvienotās Karalistes pilsoṇi vai bezvalstnieki, kam piešḳirts bezvalstnieka statuss Latvijas Republikā, Eiropas Savienības dalībvalstī, Eiropas Ekonomikas zonas valstī, Šveices Konfederācijā vai Lielbritānijas un Ziemelīijijas Apvienotajā Karalistē, šobrīd nav iespējas pārliecināties, ka vecāks, kurš dod piekrišanu vai pilnvaru bērna izbraukšanai ārpus valsts, rīkojas pēc vienošanās ar otru vecāku vai ka atḷaujas devējam ir pieškirta atsevišḳas aizgādības tiesības.

Lai novērstu konstatētās nepilnības, nepieciešams ar tiesisko regulējumu noteikt, ka bērna nodošana citas personas aprūpē (bērna fiziska šķiršana no vecākiem) ir iespējama tikai gadījumā, ja šai personai ir izdota pilnvara bērna tiesību un interešu pārstāvībai, turklāt šāda pilnvara ir jāizdod abiem vecākiem kopīgi, ja tiem ir kopīga aizgādība.

Latvijas tiesiskajā regulējumā paredzēts, ka faktiski bērna likumisko pārstāvju savstarpējā vienošanās un/vai otra vecāka dota piekrišana tam, ka bērns drīkst šḳērsot valsts robežu, ir vienīgais pierādỉjums, uz kā pamata tiek konstatēta prettiesiska bērna izvešana no valsts. Vienlaikus tiesību normās nav noteikts, ka bērna likumisko pārstāvju vienošanās vai piekrišana bērna izbraukšanai no valsts jābūt noformētai tikai rakstveidā.

Fakta, ka bērns ticis izvests no valsts prettiesiski, konstatēšana notiek, pamatojoties uz Eiropas Savienības Padomes Regulas Nr. 2201/2003 17. panta un 1980. gada Hāgas konvencijas par starptautiskās bērnu nolaupīšanas civiltiesiskajiem aspektiem 11. pantā paredzētajiem apstāklịiem, n̦emot vērā tās valsts nacionālos tiesību aktus par bērnu valsts robežas šḳērsošanu, no kuras bērns ir prettiesiski aizvests. 
Inga Kudeikina, Sanita Vanaga. Bērna pārstāvības nodrošināšana

Latvijas Republikā un izceḷojot: problēmjautājumi

\section{Problems of Ensuring a Child's Representation: when a Child is in Latvia and Travelling outside the Country}

\section{Abstract}

The article analyses the issues of child representation. The article has two parts. Special attention is paid to cases when a child leaves Latvia. Analysis of the legal framework indicates that in some cases a child is not represented. This happens when a child is not with a parent and the parent has not authorised another person to represent the child. The law allows for such a situation. However, such situation violates the rights of a child. It has been determined that the procedure for a child leaving Latvia is incomplete. It does not ensure that the child can be so illegally removed. Stronger regulation is needed. There must always be someone authorised to represent a child.

Keywords: child representation, child removal documents, child abduction.

\section{Avoti un literatūra}

\section{Tiesību akti}

1. ANO Bērnu tiesību konvencija: starptautisks dokuments: pieṇemta 20.11.1989. un stājusies spēkā 02.09.1990. Latvijas Vēstnesis. 237(5297), 28.11.2014. Iegūts no: https://likumi.lv/ta/lv/ starptautiskie-ligumi/id/1150 [sk. 02.01.2019.].

2. Bārintitiesu likums. Latvijas Republikas likums: pien̦emts 22.06.2006., stājies spēkā 01.01.2007. Latvijas Vēstnesis. 107(3475), 07.07.2006.; Latvijas Republikas Saeimas un Ministru Kabineta Zinotājs. 15, 10.08.2006.

3. Bērnu tiesību aizsardzības likums. Latvijas Republikas likums: pieñemts 19.06.1998., stājies spēkā 22.07.1998. Latvijas Vēstnesis. 199/200 (1260/1261), 08.07.1998.; Latvijas Republikas Saeimas un Ministru Kabineta Ziñotājs. 15, 04.08.1998.

4. Civillikums. Pirmā daḷa. G̦imenes tiesïbas. Latvijas Republikas likums: piennemts 28.01.1937., stājies spēkā 01.09.1993.; Valdības Vēstnesis. 41, 20.02.1937.

5. Civillikums. Ceturtā daḷa. Saistîbu tiesības. Latvijas Republikas likums: pieṇemts 28.01.1937., stājies spēkā 01.03.1993.; Valdības Vēstnesis. 46, 26.02.1937.

6. Civilprocesa likums: Latvijas Republikas likums: pieṇemts 14.10.1998. un stājies spēkā 01.03.1999. Latvijas Vēstnesis. 326/330(1387/1391), 03.11.1998.

7. Kārtība, kādā bērni škẹērso valsts robežu: Latvijas Republikas Ministru kabineta noteikumi Nr. 721: pienemti 03.08.2010. un stājušies spēkā 14.08.2010. Latvijas Vēstnesis. 128(4320), 13.08.2010.

8. Kārtība, kādā Latvijas centrālā iestāde atbilstoši 1980. gada 25. oktobra Hāgas konvencijai par starptautiskās bērnu nolaupīšanas civiltiesiskajiem aspektiem veic tajā minētās darbības un sadarbojas ar citām valsts un pašvaldību iestādēm: Latvijas Republikas Ministru kabineta noteikumi Nr. 322: pieņemti 15.05.2007. un stājušies spēkā 18.05.2007. Latvijas Vēstnesis. 79(3655), 17.05.2007.

9. Konvencija par starptautiskās bērnu nolaupī̌sanas civiltiesiskajiem aspektiem: starptautisks dokuments: pieñemta 25.10.1980. un stājusies spēkā 01.02.2002. Latvijas Vēstnesis. 151 (2538), 23.10.2001. 
Inga Kudeikina, Sanita Vanaga. Bērna pārstāvības nodrošināšana

Latvijas Republikā un izceḷojot: problēmjautājumi

10. Konvencija par jurisdikciju, piemērojamiem tiesību aktiem, atzīšanu, izpildi un sadarbību attiecībā uz vecāku atbildību un bērnu aizsardzības pasākumiem: starptautisks dokuments: pieṇemta 19.10.1996.

11. Latvijas Republikas Satversme: Latvijas valsts likums: pieṇemta 15.02.1922. un stājusies spēkā 07.11.1922. Latvijas Vēstnesis. 43, 01.07.1993.

12. Latvijas Republikas valsts robežas likums: Latvijas valsts likums: pieṇemts 12.11.2009. un stājies spēkā 16.12.2009. Latvijas Vēstnesis. 189(4175), 02.12.2009.

13. Notariāta likums. Latvijas Republikas likums: pieṇemts: 01.06.1993., stājies spēkā 01.09.1993. Latvijas Vēstnesis. 48, 09.07.1993.; Latvijas Republikas Augstākās Padomes un Valdības Ziṇotājs. 26/27, 05.07.1993.; Diena. 137, 09.07.1993.

14. Pacientu tiesību likums. Latvijas Republikas likums: pieṇemts 17.12.2009., stājies spēkā 01.03.2010. Latvijas Vēstnesis. 205(4191), 30.12.2009.

15. Par Hāgas konvencijas par starptautiskās bērnu nolaupī̌̌anas civiltiesiskajiem aspektiem: pieṇemts 04.10.2001. un stājies spēkā 23.10.2001. Latvijas Vēstnesis. 151, 23.10.2001.

16. Padomes Regula (EK) Nr. 2201/2003. Iegūts no: https://eur-lex.europa.eu/legal-content/LV/TXT/ PDF/?uri=CELEX:32003R2201\&from $=$ LV [sk. 01.08.2019].

17. Personu apliecinošu dokumentu likums: Latvijas Republikas likums: pieṇemts 12.01.2012. un stājies spēkā 15.02.2012. Latvijas Vēstnesis. 18(4621), 01.02.2012.

\section{Literatūra}

18. Apinis, M., 2002. Juridisko terminu vārdnīca. Rīga: SIA “Kamene”.

19. Bukovskis, V., 1933. Civīlprocesa mācības grāmata. Rīga.

20. LR Tieslietu ministrija. 13.02.2018. Ja bērns aizvests no Latvijas uz ārvalsti. Iegūts no: https:// www.tm.gov.lv/lv/cits/ja-berns-aizvests-no-latvijas-uz-arvalsti [sk. 03.08.2019.].

21. Jakubaṇecs, V., 2005. Juridiski terminolog̣iskā skaidrojošā vārdnīca. Rīga: "P\&K".

22. Juridiskās zinātnes aktuālās problēmas, 2012. Rakstu krājums. Rīga: Zvaigzne ABC.

23. Kudeikina, I., Palkova, K., 2016. Issues of Legal Organization of the Patient-Health Care Professional Relationship. European Journal of Interdisciplinary Studies. 1(2). Iegūts no: http:// journals.euser.org/files/articles/ejms_jan_apr_16_nr2/Inga.pdf [sk. 04.08.2019.]

24. Sardenberg, M., 1999. Comments on the globalization of child law. Globalization of Child Law (The Role of the Hague Conventions). Ed. by Sharon Detrick and Paul Vlaardingerbroek. Martinus Nijhoff Publishers, 25.

\section{Tiesu prakse}

25. Administrativās rajona tiesas 2013. gada 10. septembra spriedums lietā Nr. A420436613. Iegūts no: https://www.tiesas.lv/Media/Default/Admin.tiesu\%20spriedumi/Admin.raj.tiesas\%20spriedumi/2013/Septembris/10.09.2013/AL_1009_raj_A-04366-13.pdf [sk. 30.07.2019.].

26. Eiropas Cilvēktiesību tiesas 26.11.2013. spriedums lietā X pret Latviju, iesnieguma Nr. 27853/09. Iegūts no: https://www.tiesas.lv/Media/Default/ECT\%20spriedumi\%20un\%201\%C4\%93mumi/ CASE\%20OF\%20X\%20v\%20\%20LATVIA_EN_LV.doc [sk. 05.08.2019.].

27. Latvijas Republikas Augstākās tiesas Civillietu departamenta 2017. gada lēmums lietā Nr. SKC[D]/2017. Iegūts no: http://www.at.gov.lv/downloadlawfile/5162 [sk. 05.08.2019.].

28. Latvijas Republikas Augstākās tiesas Administratīvo lietu departamenta 2015. gada 27. novembra spriedums lietā Nr. SKA-1142/2015. Iegūts no: http://www.at.gov.lv/downloadlawfile/4352 [sk. 05.08.2019.]. 